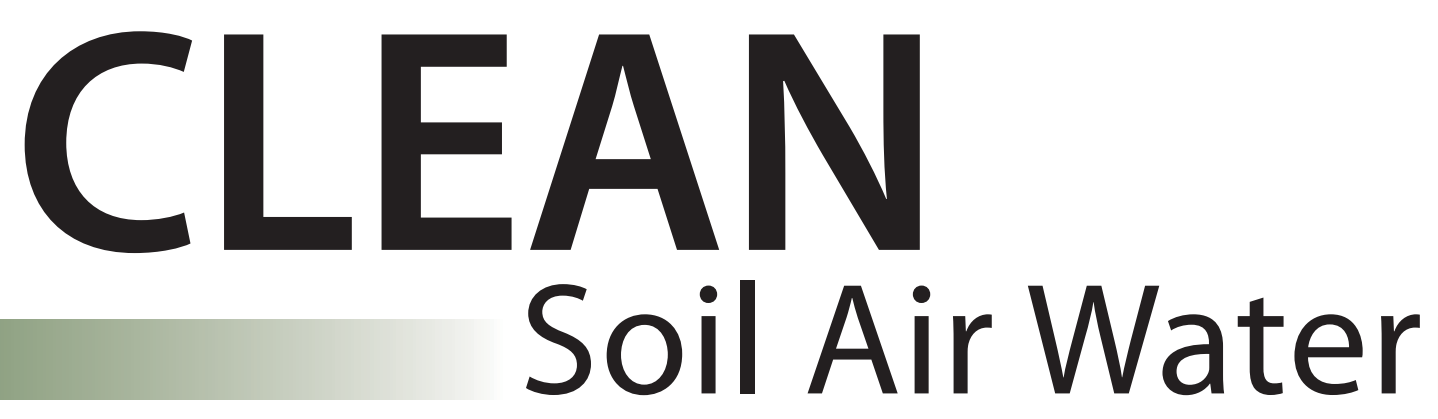

Renewables

Sustainability

Environmental Monitoring

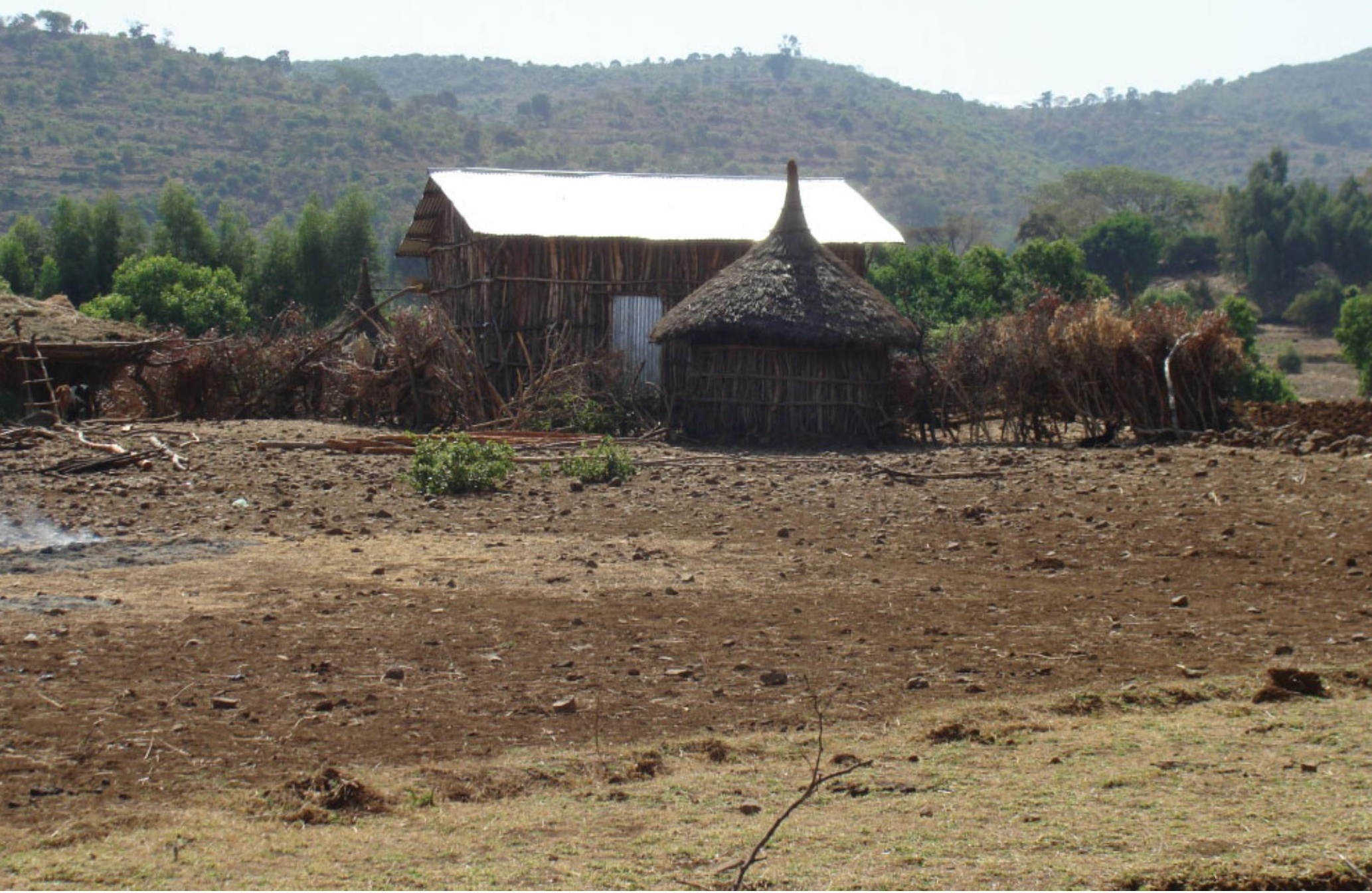


ícaro T. A. Moreira ${ }^{1,2}$

Olívia M. C. Oliveira ${ }^{1}$

Thomas Azwell ${ }^{3}$

Antonio F. S. Queiroz ${ }^{1}$

Rita M. W. Nano ${ }^{4}$

Eliane S. Souza ${ }^{5}$

José A. S. A. Dos Anjos ${ }^{1,2}$

Ramilla V. Assunçãó ${ }^{1}$

Lucas Medeiros Guimarães ${ }^{1}$

${ }^{1}$ Departamento de Oceanografia, Núcleo de Estudos Ambientais, Instituto de Geociências,

Universidade Federal da Bahia,

Salvador-BA, Brazil

${ }^{2}$ Departamento de Arquitetura, Engenharia e TI, Universidade Salvador, UNIFACS, Salvador, Brazil

${ }^{3}$ University of California, Berkeley, California, USA

${ }^{4}$ Instituto Federal de Educação, Ciência e Tecnologia da Bahia, Salvador, Brazil

${ }^{5}$ Universidade Estadual do Norte Fluminense Darcy Ribeiro, UENF. Macaé-RJ, Brazil
Research Article

\section{Strategies of Bioremediation for the Degradation of Petroleum Hydrocarbons in the Presence of Metals in Mangrove Simulated}

Contamination by oil spills in coastal ecosystems, especially in mangrove zones, has been common in countries with oil industry. The aim of this study was, therefore, to evaluate the efficiency of application of the two models developed for pilot-scale remediation, intrinsic bioremediation (indigenous microorganisms), and phytoremediation (Avicennia schaueriana). The degradation of hydrocarbons was determined by gas chromatography (GS) with flame ionization detector. The metals $\mathrm{Al}, \mathrm{Fe}, \mathrm{Pb}, \mathrm{Cr}, \mathrm{Cu}, \mathrm{Zn}$, and $\mathrm{Ni}$ were determined by flame atomic absorption spectrometry in the mangrove simulated with sediment of Todos os Santos Bay, Brazil. These models also monitor other biogeochemical parameters (nitrogen, phosphorus, total organic carbon, $\mathrm{pH}$, redox potentioal, dissolved oxygen, salinity, temperature, bacterial density). The integrated assessment of data showed that both techniques were effective in degrading organic compounds from oil but that phytoremediation is the most efficient (89\% removal). The intrinsic bioremediation model has no direct correlation with metal concentrations, but a positive correlation with $\mathrm{Al}$ and $\mathrm{Ni}$ was found in the hydrocarbon removal by phytoremediation. Avicennia schaueriana represents efficiency in phytoextraction and phytostimulation. The results suggest that the phytoremediation model, through its various mechanisms, may become a technique for the removal of petroleum hydrocarbons in the presence of metals in mangrove ecosystems near industrial areas.

Keywords: Avicennia schaueriana; Interstitials sediments; Phytoremediation; Total petroleum hydrocarbons

Received: December 13, 2013; revised: July 25, 2014; accepted: September 2, 2014

DOI: $10.1002 /$ clen.201300939

\section{Introduction}

The development of models and remediation processes for application to mangrove zones affected by the presence of petroleum hydrocarbons in conjunction with metals has become a major technological requirement in the countries of coastal regions with a strong oil industry $[1,2]$. A tool that presents contingency plans for oil spills is badly needed, especially when regarding an ecosystem with ecological and economic importance such as a mangrove, ranked as one of the most sensitive habitats in the world ranking of coastal areas in the NOAA Environmental Sensitivity Index [3].

The mangrove ecosystems have special characteristics, such as low oxygen availability, average salinity, and low diversity of

Correspondence: Prof. Í. T. A. Moreira, Departamento de Oceanografia, Núcleo de Estudos Ambientais, Instituto de Geociências, Universidade Federal da Bahia, Campus de Ondina, 40170-290, Salvador-BA, Brazil E-mails: icarotam@ufba.br; icarotam@gmail.com; icaro.moreira@pro.unifacs.br

Abbreviations: CFU, colony forming unit; DO, dissolved oxygen; Eh redox potential; PCA, principal component analysis; TN, total nitrogen; TOC, total organic carbon; TOM, total organic matter. microorganisms in relation to other environmental categories. These special characteristics can provide a greater or lesser biodegradation of toxic compounds. However, the impact of oil on mangroves depends on the types of associated pollutants, their concentration, toxicity, distribution, and also their retention time in the water and interstitials sediments [3]. In many cases, the mangrove can behave as reservoirs for pollutants, such as metals coming from marine or terrestrial environments. The toxicity of the contamination is higher when metals are present and the degree of difficulty involved in the removal of organic compounds derived from petroleum becomes more complex $[4,5]$.

A technique widely used in mangrove areas affected by oil is the intrinsic bioremediation (Natural Attenuation Monitored), which is a process based on natural factors where indigenous microorganisms will act to degrade petroleum hydrocarbons that are bioavailable in the interstitials sediments through a redox reaction $[6,7]$. However, this technique depends on monitoring geochemical indicators $(\mathrm{pH}$, redox potential (Eh), dissolved oxygen (DO), temperature, nutrients) as well as microbial density. This remedial option has been used mainly for its low cost and its wide acceptance [8].

In recent years, phytoremediation has been applied intensely in areas affected by oil [9-14]. The phytoremediation technique is a 
process that applies plant systems, often associated with microorganisms, to remove, degrade, and immobilize toxic substances in the environment. The plant species that perform phytoremediation may also have a tolerance to high concentrations of contaminants in their roots, stems, and leaves [15]. Plant species perform phytoremediation by several physiological mechanisms, depending on the physicochemical nature of the pollutant or property. These physiological mechanisms may be classified as phytoextraction, phytodegradation, phytostabilization, phytostimulation, and phytovolatilization. Large areas can be remediated in several ways at a low cost. Phytoremediation offers opportunities to remediate contaminated water, soil, subsoil, and interstitials sediments, while beautifying the environment. Paradoxically, the time required to obtain satisfactory results can sometimes be long. The concentration of the contaminant and the presence of toxins must be within the tolerance limits of the plant used in order to avoid compromising the treatment [16].

In mangrove interstitials, sediments contaminated by metals and hydrocarbons, it is difficult to choose the best technique to be applied. Few organisms can tolerate a heterogeneous contamination, even though some microbes use oil as an energy source [17]. The objective of this study was therefore to evaluate the efficiency of two models in pilot-scale remediation, the intrinsic bioremediation (indigenous microorganisms) and phytoremediation (Avicennia schaueriana) as applied to the degradation of hydrocarbons associated with metals ( $\mathrm{Al}, \mathrm{Fe}, \mathrm{Pb}, \mathrm{Cr}, \mathrm{Cu}, \mathrm{Zn}$, and $\mathrm{Ni}$ ) in mangrove interstitials sediments and to monitor other biogeochemical parameters ( $\mathrm{pH}, \mathrm{Eh}, \mathrm{DO}$, salinity, temperature, bacterial density).

\section{Materials and methods}

\subsection{Preparation of simulated mangrove}

\subsubsection{Sediment}

In a mangrove ecosystem located north of Todos os Santos Bay between the cities of Candeias and São Francisco do Conde, Bahia, Brazil, in summer 2010, sediment samples at $0-30 \mathrm{~cm}$ depth were collected with a stainless sampler. These samples were sieved $(4 \mathrm{~mm}$ sieve) and homogenized. Five sub-samples of sediments were collected, lyophilized for $72 \mathrm{~h}$ and sieved through $2 \mathrm{~mm}$ mesh to determine the physical and chemical properties of the selected sediment. The organic matter in the sediments was determined using a modified Mebius method [18]. Total nitrogen (TN) was determined by Kjeldahl digestion, distillation and titration [19]. The method of extraction to evaluate phosphorus (P) was developed by Olsen and Dean [20]. After organic matter was removed with $30 \%$ $\mathrm{H}_{2} \mathrm{O}_{2}$, particle size distribution was determined using the method of Folk and Ward [21]. After homogenization, sediment samples were mixed at a ratio of 1:10 with the oil residue found in the same area, a region active in the petroleum industry (extraction, transportation and refining). Five replicates of homogenized sediment samples were collected for analysis of the initial concentration of total petroleum hydrocarbons (TPHs) and (aluminum (Al), iron (Fe), lead $(\mathrm{Pb})$, chromium $(\mathrm{Cr})$, copper $(\mathrm{Cu})$, zinc $(\mathrm{Zn})$, and nickel $(\mathrm{Ni})$ by flame atomic absorption spectroscopy (SpectrAA 220, Varian, Mulgrave, Victoria, Australia). TPHs were determined by gas chromatography (GC) (Varian CP 3800, Varian, CA) equipped with a DB-5 capillary column (15 m length, $0.25 \mathrm{~mm}$ id, $0.25 \mathrm{~lm}$ film thickness) and flame ionization detector. We collected sediment in a reference area from another study for comparison to the parameters analyzed in this study [22].

\subsubsection{Remediation models}

This research was developed on a pilot-scale with two remediation models: The first model was intrinsic bioremediation (monitored natural attenuation) and the second model was phytoremediation (A. schaueriana - black mangrove). These models were developed by building units of simulated mangrove, and the material used was glass $(50 \times 30 \times 40 \mathrm{~cm})$. Within each simulated unit, six glass tubes $(30 \times 10 \times 10 \mathrm{~cm})$ were added. Each tube would be a repetition for each developed model, resulting in three units of simulation with six replicates for each model. The experiment was conducted for 3 months in a greenhouse near the mangrove in which the sediment and also waste oil samples were collected. The tidal regime was simulated daily in each unit to provide models for remediation conditions closer to a mangrove ecosystem. The choice of plant species used in the phytoremediation model of this study was based on pre-tests done earlier by our group, attesting to the ability of the plant species to grow in sediments with high concentrations of petroleum hydrocarbons [23]. Seedlings of A. schaueriana were collected at low tide, considering their height (average: 3 months old), defining a standard sample.

\subsubsection{Monitoring}

For monitoring of the sediments studied in the two models, the samples were collected at five pre-set times $(7,15,30,60,90$ days). TPH concentrations were analyzed according to the US EPA Method 8015B, metals were determined by the US EPA Method 3015, macronutrients (TN, P), total organic carbon (TOC), total organic matter (TOM), pH, and Eh by potentiometry using a $\mathrm{pH} / \mathrm{mV}$ HandyLab1, (Schott Glaswerke Mainz). The salinity was measured by the index of refraction using the portable refractometer Atoga S/Mill-E. Dissolved oxygen (DO) was measured with a WTW Oximeter OXI 3151 (Schott-Geräte). Bacterial density was established using the microgotas method [24]. These parameters were analyzed to obtain an integrated assessment of biodegradation of organic compounds derived from petroleum in the presence of metals. Replicate analysis of these reference materials showed good accuracy, with recovery rates for metals between 94 and $103 \%$ for TPHs and 92 and 101\% for sediment.

\subsubsection{Statistical analysis}

Integrated assessment of the data for the two models of remediation was also made possible by statistical tests, such as principal component analysis (PCA) of the concentrations of all data analyzed in surface sediments of each type of remediation, in order to find the main variables influencing the degradation of TPHs. Other statistical tests were applied: The K-means, the Kolmogorov-Smirnov test, parametric Tukey-Kramer, and Pearson correlation. All the statistical evaluation was performed using the software STATISTICA 9.0 and GraphPad Software.

\section{Results and discussion}

\subsection{Monitoring of the experiment}

Before the start of the experiments, a pre-established set of parameters was analyzed in the sediment before (reference) and 


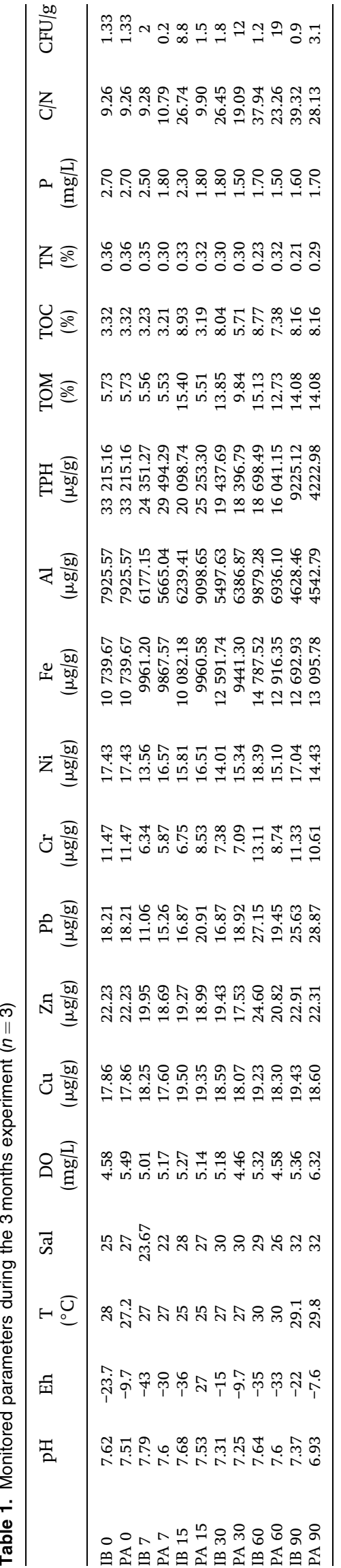

after mixing with the oil (contaminated, day 0). During the 3-month experiment, the same parameters were also monitored as shown in Table 1. The results showed that after the homogenization of the sediment with the oil, there was an increase in the concentration of most metals tested except for iron (Fe). However, all values were below the threshold effect level and were not toxic to biota [21]. In other experiments, this same behavior was also observed relative to the higher concentration of metals in sediments contaminated with oil $[22,23]$. The $\mathrm{pH}$ values ranged from 7.31 to 7.90 for intrinsic bioremediation and from 6.93 to 7.60 for phytoremediation. Both remediation methods maintained $\mathrm{pH}$ within the expected range for optimum degradation of oil [24]. For the monitoring of temperature $\left(25-30^{\circ} \mathrm{C}\right)$, the averages where the greatest enzymatic activity of microorganisms in bioremediation occurs were classified as ideal [25]. The salinity during the experiment in both models showed a range of variation that would not jeopardize the degradation of microorganisms [26].

Concentrations of macronutrients ( $\mathrm{N}$ and $\mathrm{P}$ ) and organic matter in sediments also were within the range that is expected for degradation by the biota in sediments impacted by organic compounds [24].

\subsection{Biodegradation}

The removal of hydrocarbons derived from petroleum in the presence of metals was evaluated in two models of biodegradation during remediation in a 90-day experiment. Within 15 days of the initial model intrinsic bioremediation of a higher efficiency was verified compared to phytoremediation, which has become more efficient from day 15 onwards. This result was expected, since plants need a period of days to adapt to the contaminated sediment in order to reach their maximum efficiency at removing contaminants [27]. After 3 months, A. schaueriana removed compounds in sediments from the initial value of $33.2-4.2 \mu \mathrm{g} / \mathrm{g}$, while intrinsic bioremediation showed a decrease from 33.2 to $9.2 \mu \mathrm{g} / \mathrm{g}$ (Fig. 1). Phytoremediation was able to remove hydrocarbons from the sediment about $19 \%$ more efficiently than the intrinsic bioremediation. This increased efficiency of phytoremediation relative to the intrinsic bioremediation corroborates other studies of sediments affected by oil organic compounds [28, 29].

The values of the metals in the two models during the 90 days remained relatively constant, though we observed a moderate removal $(18 \%)$ of nickel $(\mathrm{Ni})$ and low removal $(8 \%)$ of chromium $(\mathrm{Cr})$ by the black mangrove (Fig. 2). This sequence of degradation and higher removal of the template for phytoremediation was consistent with the results of the analysis of bacterial density in the sediment.

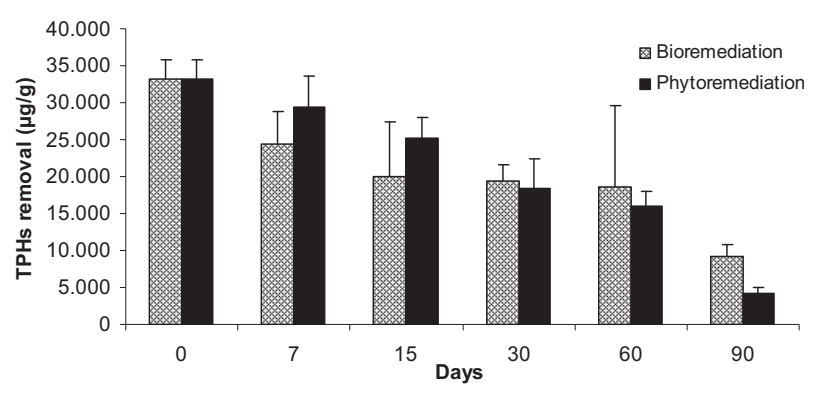

Figure 1. TPH's concentrations in the mangrove sediment a function of time. 


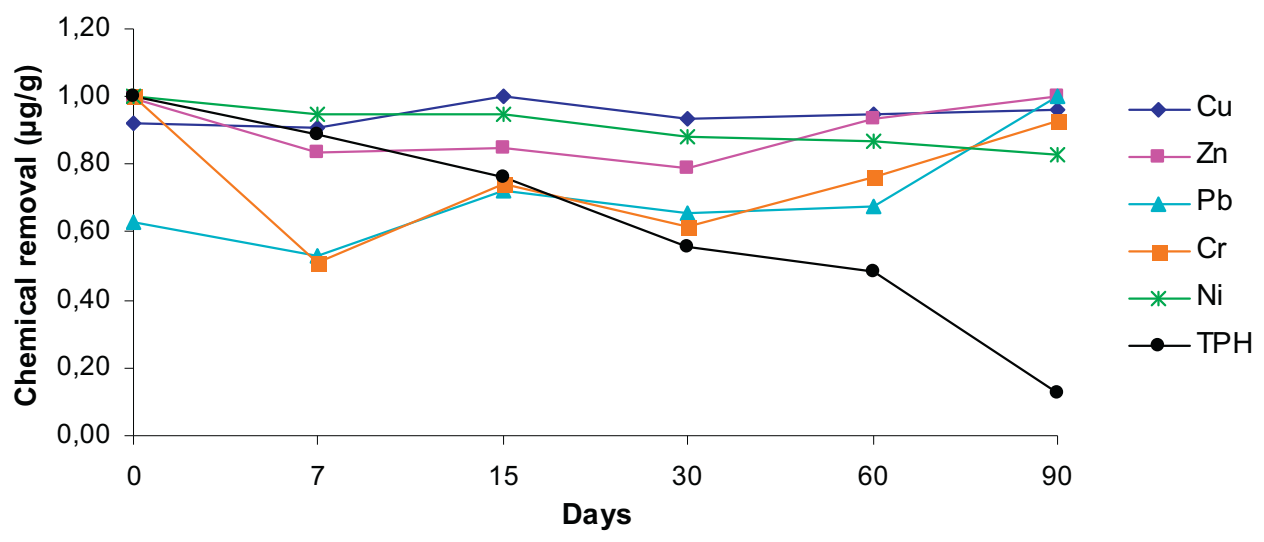

Figure 2. Metals concentrations in the mangrove sediment a function of time.

After applying models of remediation in sediments, a significant increase in the number of microorganisms was observed after 7 days in both models, showing a significant difference from the original sediment sample, $8.3 \times 10^{6}$ (intrinsic bioremediation) and $1.5 \times 10^{6}$ (phytoremediation by A. schaueriana) colony forming units $(\mathrm{CFU}) \mathrm{g}^{-1}$, respectively (Fig. 3). After 30 days, an increase of microbial communities in phytoremediation as well as the quantified values of $12 \times 10^{6}$ to $19 \times 10^{6} \mathrm{CFU} \mathrm{g}^{-1}$ were observed. There was a drastic drop in the number of microorganisms in the intrinsic bioremediation model $\left(1.8 \times 10^{6} \mathrm{CFU} \mathrm{g}^{-1}\right)$. These results suggest that the black mangrove should have a high capacity to stimulate the degradation of organic compounds by bacterial communities, through some allelopathic compounds (such as carbohydrates, organic acids, and amino acids) are similar to the organic compounds that stimulate the defenses of communities or other compounds that are provided by the action of the plants' roots, stimulating the microorganisms, thereby corroborating other studies [30, 31].

\subsection{Integrated assessment}

To evaluate how the metals and other parameters in this experiment affected the removal of organic compounds derived from petroleum, we used the Pearson correlation to get an indication of the strength and direction of the linear relationship between variables in both of the models of remediation that were applied. In intrinsic bioremediation (Table 2), a strong negative correlation was observed between the concentrations of copper $(\mathrm{Cu})$ and the concentration of
TPHs throughout the experiment. This negative correlation indicates that there was a greater availability of the metal during the biodegradation of hydrocarbons, which may have inhibited greater removal of indigenous microorganisms [32]. No strong correlation was observed for the other metals. For the macronutrients $(\mathrm{N}, \mathrm{P})$ and DO, the correlation with the removal of TPHs was strongly positive, indicating that in this model of remediation, the oxygen and nutrients in the sediment were more available for the degradation of organic compounds. This correlation agrees with information published in the literature [33]. When the phytoremediation model was evaluated, a strong positive correlation between the removal of hydrocarbons and nickel (Ni) and aluminum (Al), as well as the consumption of nitrogen and phosphorus was observed (Table 3). In the phytoremediation model, A. schaueriana performed phytoextraction of metals from the sediment, and associated microorganisms also removed the oil. This same behavior has already been seen applied to other plant species in contaminated sediments [34, 35]. The degradation of the hydrocarbons in black mangrove may have used the mechanism of phytostabilization for lead $(\mathrm{Pb})$, as a negative correlation between the variables was observed.

With the objective of obtaining a smaller number of linear combinations than the ones found in the Pearson correlation, an analysis of the principal component models remediation (PCA) was also carried out. Intrinsic bioremediation in the two main factors could explain $79.74 \%$ of the variation in the data analyzed, with the first factor explaining $55.76 \%$ and second $23.98 \%$ (Fig. 4). The values

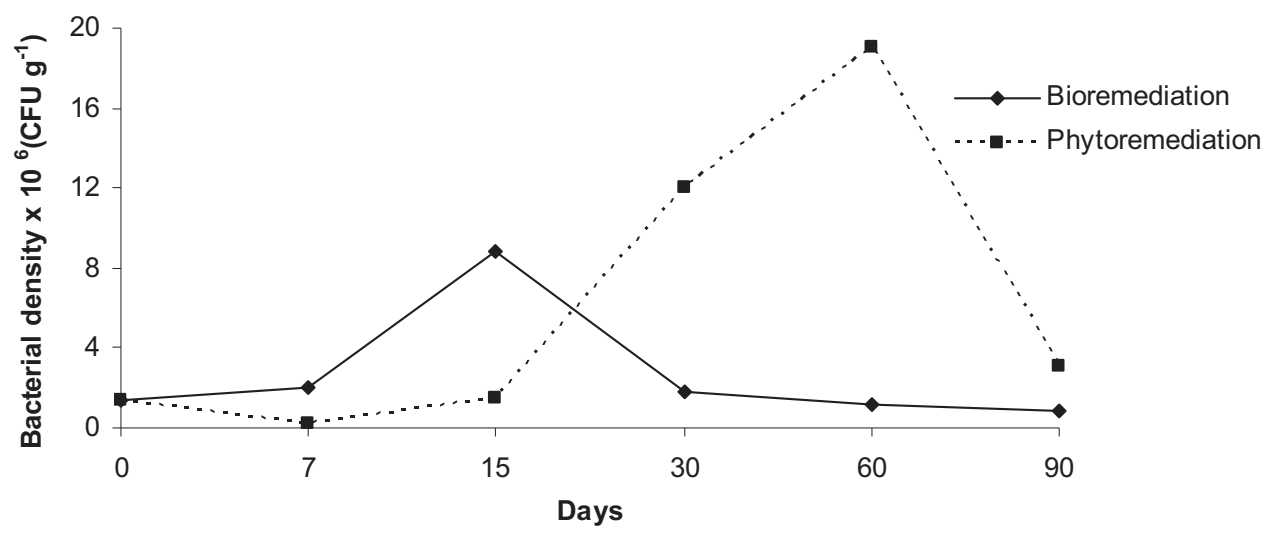

Figure 3. Total count of bacteria during 90 days, comparison between models $(n=3)$. 
Table 2. Pearson correlation in intrinsic bioremediation

\begin{tabular}{|c|c|c|c|c|c|c|c|c|c|c|c|c|c|c|c|c|c|}
\hline & $\mathrm{pH}$ & Eh & $\mathrm{T}$ & Sal & DO & $\mathrm{Cu}$ & $\mathrm{Zn}$ & $\mathrm{Pb}$ & $\mathrm{Cr}$ & $\mathrm{Ni}$ & $\mathrm{Fe}$ & $\mathrm{Al}$ & TOM & TOC & $\mathrm{TN}$ & $\mathrm{P}$ & $\mathrm{TPH}$ \\
\hline $\mathrm{pH}$ & 1 & & & & & & & & & & & & & & & & \\
\hline Eh & -0.92 & 1 & & & & & & & & & & & & & & & \\
\hline $\mathrm{T}$ & -0.23 & 0.18 & 1 & & & & & & & & & & & & & & \\
\hline Sal & -0.80 & 0.58 & 0.31 & 1 & & & & & & & & & & & & & \\
\hline DO & -0.31 & -0.07 & 0.10 & 0.74 & 1 & & & & & & & & & & & & \\
\hline $\mathrm{Cu}$ & -0.21 & -0.09 & 0.04 & 0.73 & 0.90 & 1 & & & & & & & & & & & \\
\hline $\mathrm{Zn}$ & -0.04 & 0.03 & 0.93 & 0.27 & 0.09 & 0.17 & 1 & & & & & & & & & & \\
\hline $\mathrm{Pb}$ & -0.39 & 0.28 & 0.76 & 0.71 & 0.46 & 0.57 & 0.85 & 1 & & & & & & & & & \\
\hline $\mathrm{Cr}$ & -0.17 & 0.23 & 0.88 & 0.32 & -0.02 & 0.11 & 0.97 & 0.86 & 1 & & & & & & & & \\
\hline $\mathrm{Ni}$ & -0.01 & 0.08 & 0.64 & 0.29 & 0.03 & 0.30 & 0.87 & 0.84 & 0.92 & 1 & & & & & & & \\
\hline $\mathrm{Fe}$ & -0.46 & 0.32 & 0.79 & 0.65 & 0.50 & 0.39 & 0.72 & 0.84 & 0.70 & 0.54 & 1 & & & & & & \\
\hline $\mathrm{Al}$ & 0.48 & -0.34 & 0.43 & -0.30 & -0.22 & -0.14 & 0.59 & 0.33 & 0.57 & 0.60 & 0.40 & 1 & & & & & \\
\hline TOM & -0.47 & 0.22 & 0.05 & 0.85 & 0.86 & 0.89 & 0.13 & 0.60 & 0.14 & 0.27 & 0.57 & -0.05 & 1 & & & & \\
\hline TOC & 0.50 & -0.23 & -0.71 & -0.82 & -0.73 & -0.68 & -0.67 & -0.87 & -0.60 & -0.50 & -0.82 & 0.00 & -0.65 & 1 & & & \\
\hline $\mathrm{TN}$ & 0.67 & -0.38 & -0.50 & -0.91 & -0.83 & -0.68 & -0.39 & -0.72 & -0.35 & -0.23 & -0.83 & 0.13 & -0.79 & 0.92 & 1 & & \\
\hline $\mathrm{P}$ & -0.52 & 0.24 & 0.43 & 0.91 & 0.86 & 0.87 & 0.46 & 0.83 & 0.44 & 0.46 & 0.76 & -0.02 & 0.90 & -0.91 & -0.93 & 1 & \\
\hline $\mathrm{TN}$ & 0.52 & -0.16 & -0.24 & -0.85 & 0.91 & -0.83 & -0.18 & -0.54 & -0.09 & -0.07 & -0.49 & 0.44 & -0.74 & 0.84 & 0.87 & 0.86 & 1 \\
\hline
\end{tabular}

Bold values signify those with significant correlations in the study.

Table 3. Pearson correlation in intrinsic phytoremediation (A. schaueriana)

\begin{tabular}{|c|c|c|c|c|c|c|c|c|c|c|c|c|c|c|c|c|c|}
\hline & $\mathrm{pH}$ & Eh & $\mathrm{T}$ & Sal & DO & $\mathrm{Cu}$ & $\mathrm{Zn}$ & $\mathrm{Pb}$ & $\mathrm{Cr}$ & $\mathrm{Ni}$ & $\mathrm{Fe}$ & $\mathrm{Al}$ & TOM & TOC & $\mathrm{TN}$ & $\mathrm{P}$ & $\mathrm{TPH}$ \\
\hline $\mathrm{pH}$ & 1 & & & & & & & & & & & & & & & & \\
\hline Eh & -0.17 & 1 & & & & & & & & & & & & & & & \\
\hline $\mathrm{T}$ & -0.38 & -0.66 & 1 & & & & & & & & & & & & & & \\
\hline Sal & -0.88 & 0.37 & 0.29 & 1 & & & & & & & & & & & & & \\
\hline DO & -0.58 & 0.21 & 0.23 & 0.36 & 1 & & & & & & & & & & & & \\
\hline $\mathrm{Cu}$ & -0.19 & 0.80 & -0.22 & 0.40 & 0.16 & 1 & & & & & & & & & & & \\
\hline $\mathrm{Zn}$ & -0.27 & -0.11 & 0.58 & 0.28 & 0.69 & 0.02 & 1 & & & & & & & & & & \\
\hline $\mathrm{Pb}$ & -0.84 & 0.33 & 0.45 & 0.82 & 0.69 & 0.56 & 0.52 & 1 & & & & & & & & & \\
\hline $\mathrm{Cr}$ & -0.33 & 0.24 & 0.31 & 0.52 & 0.60 & 0.23 & 0.89 & 0.56 & 1 & & & & & & & & \\
\hline $\mathrm{Ni}$ & -0.67 & 0.20 & -0.69 & -0.60 & -0.09 & -0.23 & -0.07 & -0.67 & 0.03 & 1 & & & & & & & \\
\hline $\mathrm{Fe}$ & -0.36 & -0.32 & 0.89 & 0.34 & 0.43 & 0.16 & 0.76 & 0.65 & 0.55 & -0.61 & 1 & & & & & & \\
\hline $\mathrm{Al}$ & 0.63 & 0.57 & -0.65 & -0.25 & -0.38 & 0.42 & -0.15 & -0.38 & 0.14 & 0.64 & -0.40 & 1 & & & & & \\
\hline TOM & -0.64 & -0.32 & 0.87 & 0.62 & 0.16 & 0.13 & 0.35 & 0.69 & 0.24 & -0.94 & 0.80 & -0.61 & 1 & & & & \\
\hline TOC & -0.64 & -0.32 & 0.87 & 0.62 & 0.16 & 0.13 & 0.35 & 0.69 & -0.24 & -0.94 & 0.80 & -0.61 & 1.00 & 1 & & & \\
\hline $\mathrm{TN}$ & 0.50 & 0.20 & -0.27 & -0.19 & -0.05 & -0.03 & 0.39 & -0.33 & 0.57 & 0.73 & -0.11 & 0.73 & -0.49 & -0.49 & 1 & & \\
\hline $\mathrm{P}$ & 0.22 & 0.15 & -0.27 & -0.15 & 0.37 & -0.26 & 0.51 & -0.20 & 0.59 & 0.77 & -0.15 & 0.37 & -0.56 & -0.56 & 0.82 & 1 & \\
\hline $\mathrm{TN}$ & 0.78 & 0.06 & -0.68 & -0.71 & -0.30 & -0.35 & -0.24 & -0.83 & -0.17 & 0.97 & -0.68 & 0.61 & -0.93 & -0.93 & 0.65 & 0.64 & 1 \\
\hline
\end{tabular}

Bold values signify those with significant correlations in the study.

of TPHs, $\mathrm{Pb}, \mathrm{Cu}, \mathrm{Zn}, \mathrm{P}, \mathrm{TN}$ are well-represented on the chart where strong positive correlations were noted between $\mathrm{pH}$ and $\mathrm{P}$ and TPHs, corroborating the results of the Pearson correlation. However, this analysis showed that the concentrations of $\mathrm{Al}, \mathrm{Ni}, \mathrm{Cu}, \mathrm{Zn}, \mathrm{Fe}$, and $\mathrm{Pb}$ are independent of the removal of hydrocarbons, making it clear that all of the metals are likely to have influenced the biodegradation. This model shows a negative correlation between the variables DO, TOC, TOM, salinity, C/N with the TPHs. Some type of remediation must have occurred, because the degradation of organic compounds in sediments with indigenous microorganisms has been linked directly to the consumption of oxygen, organic matter, and nutrients [33].

When the PCA was applied to phytoremediation, the two main factors explained $72.62 \%$ of the variance, with the first principal components explaining $51.08 \%$ and the second principal components explaining $21.54 \%$ of the data that were evaluated (Fig. 5). In this model, the graph clearly represented the values of TPHs, $\mathrm{Ni}, \mathrm{Pb}$, $\mathrm{Cr}$, TN, P, Al, and Ni strongly correlated with TPHs in agreement with Pearson's correlation. Moreover, it was evident that the hydrocarbon removal was independent of the variables $\mathrm{Cr}, \mathrm{Cu}, \mathrm{Zn}, \mathrm{Pb}, \mathrm{Fe}, \mathrm{DO}$, and salinity, suggesting that these variables did not influence the biodegradation. The cause of the lack of influence on the biodegradation may be the phytostabilization of the metals, in addition to the behavior of A. schaueriana as a halophyte species in the presence of salts [36]. Moreover, a strong negative correlation between certain variables and the TPHs was not shown, although there is a moderate negative correlation between TPHs with TOC and $\mathrm{T}$, suggesting that the greater extent of degradation of compounds happened when the temperature was higher and the quantity of organic carbon in the environment was larger [37-42].

These results are different from those found for of Rizophora mangle (red mangrove) [39]. These are different species and, therefore, they have different physiologies. While the red mangrove has a strong feature for the extraction of metals, the black mangrove has a physiology that stabilize these metals in the roots, which causes it to not have the same translocation of these metals that $R$. mangle accumulation in leaves. Therefore, the metals correlation is different.

The novelty of this new manuscript is precisely because we are presenting results of different phytoremediation to another plant 


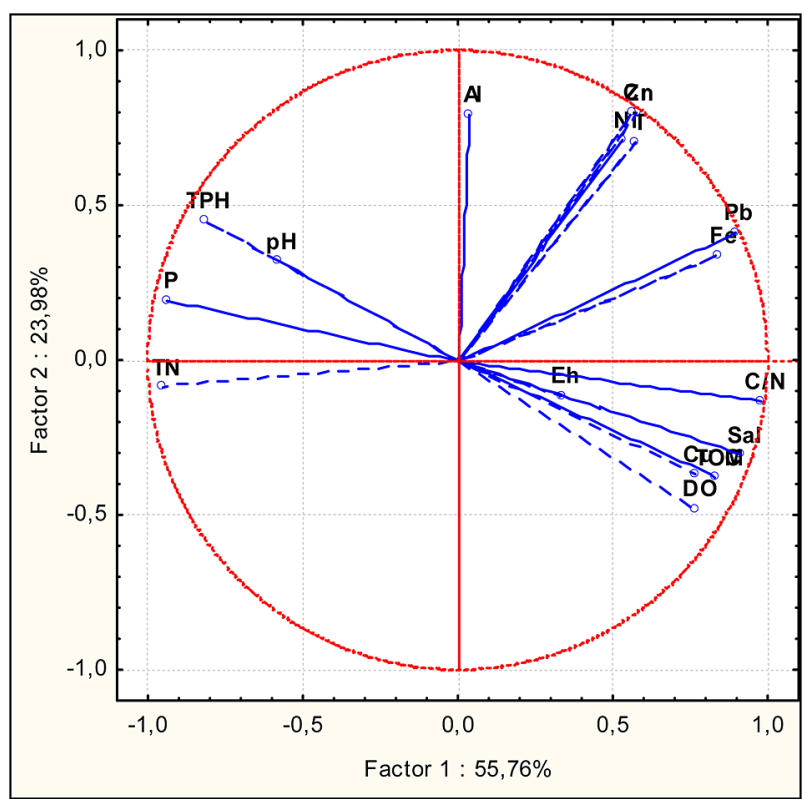

Figure 4. PCA in intrinsic bioremediation.

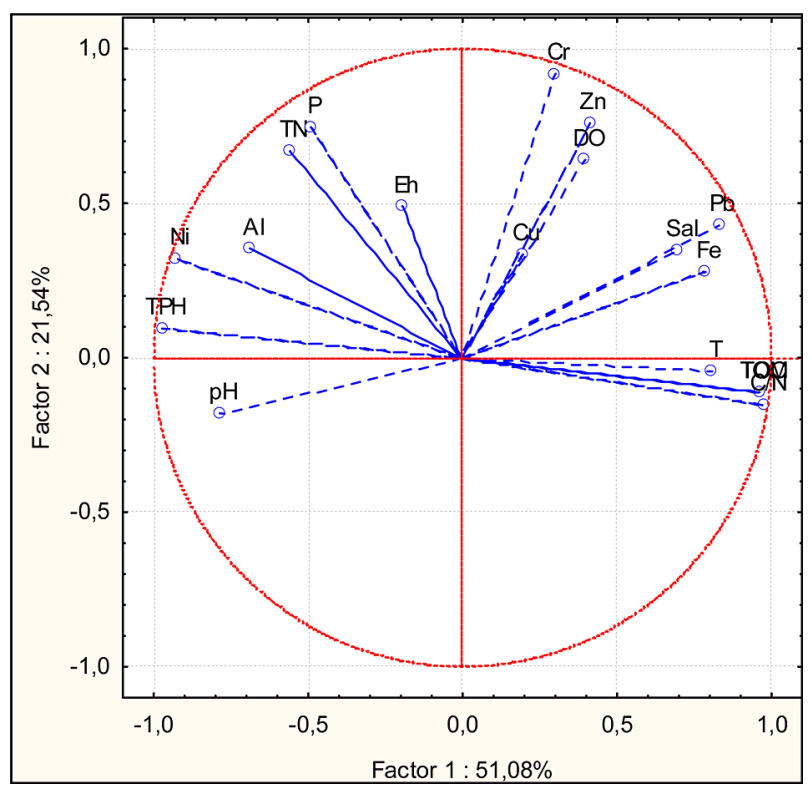

Figure 5. PCA in phytoremediation (A. schaueriana).

species (A. schaueriana) which has a higher occurrence in the world than $R$. mangle and other species, and showed different results in absorption and translocation of metals, as was proven by the statistical treatment $[43,44]$.

\section{Concluding remarks}

Regarding the application of the developed models to remediation of mangrove sediments simulated on a pilot scale, the conclusion is that phytoremediation shows a higher efficiency relative to the removal of petroleum hydrocarbons, than intrinsic bioremediation. The presence of metals did not influence bioremediation directly except for $\mathrm{Cu}$, which may have moderately inhibited the efficiency of the process. $\mathrm{Ni}$ and $\mathrm{Al}$ seem to have been absorbed by A. schaueriana while they were removed from the hydrocarbons, which may have favored the growth of microorganisms in the rhizosphere, in addition to the stimulation by the allelopathic compounds. The implementation of the phytoremediation model in areas impacted by oil activities can be important, because phytoremediation is an inexpensive, environmentally friendly, and socially correct technique. Moreover, phytoremediation may also contribute to the reduction of global warming through carbon sequestration by applied plants, showing not only local but also global importance.

\section{Acknowledgments}

This study has been carried out with the financial support of the FAPESB, FINEP, and PETROBRAS. We thank the American Journal Experts for the English revision of the manuscript.

The authors have declared no conflict of interest.

\section{References}

[1] J. L. Schnoor, L. A. Licht, S. C. McCutcheon, L. N. Wolfe, L. H. Carreira, Phytoremediation of Organic and Nutrient Contaminants, Environ. Sci. Technol. 1995, 29 (7), 318-323.

[2] E. B. Barbier, E. W. Koch, B. R. Siliman, S. D. Hacker, E. Wolanski, J. Primavera, Coastal Ecosystem Based Management With Nonlinear Ecological Functions and Values, Science 2008, 318, 321-323.

[3] National Oceanic and Atmospheric Administration (NOAA), Oil Spills in Mangroves: Planning and Response Considerations, NOAA, Washington, DC 2002.

[4] E. M. Brito, R. Duran, R. Guyoneaud, M. Goni-Urriza, T. Garcia de Oteyza, M. A. Crapez, A Case Study of In Situ Oil Contamination in a Mangrove Swamp (Rio De Janeiro, Brazil), Mar. Pollut. Bull. 2009, 58, 418-423.

[5] H. F. Santos, F. L. Carmo, J. E. S. Paes, A. S. Rosado, R. S. Peixoto, Bioremediation of Mangroves Impacted by Petroleum, Water Air Soil Pollut. 2011, 216 (1-4), 329-350.

[6] A. P. Mariano, PhD Thesis, Avaliação do Potencial de Biorremediação de Solos e de Águas Subterrâneas Contaminados com Óleo Diesel, Universidade Estadual Paulista, Rio Claro, São Paulo, Brazil 2006.

[7] A. N. Kabra, R. V. Khandare, S. P. Govindwar, Development of a Bioreactor for Remediation of Textile Effluent and Dye Mixture: A Plant-Bacterial Synergistic Strategy, Water Res. 2013, 47 (3), 10351048.

[8] R. M. Atlas, Microbial Degradation of Petroleum Hydrocarbons: An Environmental Perspective, Microbiol. Rev. 1982, 45, 180-209.

[9] J. Finn, S. Fiorenza, C. L. Oubre, C. H. Ward, Part II: Technology design/evaluation, Phytoremediation of Hydrocarbon-Contaminated Soil (Eds.: S. Fiorenza, C. L. Oubre, C. H. Ward), Lewis Publishers, Baton Rouge 2000, pp. 91-135.

[10] P. J. Harvey, B. F. Campanella, P. M. L. Castro, H. Harms, E. Lichtfouse, A. R. Schaeffner, S. Smrcek, et al., Phytoremediation of Polyaromatic Hydrocarbons, Anilines and Phenols, Environ. Sci. Pollut. Res. 2002, 9, 29-47.

[11] P. M. White, D. C. Wolf, G. J. Thomas, C. M. Reynolds, Phytoremediation of Alkylated Polycyclic Aromatic Hydrocarbons in a Crude Oil-Contaminated Soil, Water Air Soil Pollut. 2006, 169, 207-220.

[12] E. M. Sheehan, M. A. Limmer, P. Mayer, U. G. Karlson, J. G. Burken, Time-Weighted Average SPME Analysis for in Plant Determination of cVOCs, Environ. Sci. Technol. 2012, 46 (6), 3319-3325.

[13] E. M. Seeger, U. Maier, P. Grathwohl, P. Kuschk, M. Kaestner, Performance Evaluation of Different Horizontal Subsurface Flow Wetland Types by Characterization of Flow Behavior, Mass Removal and Depth-Dependent Contaminant Load, Water Res. 2013, 47 (2), 769-780. 
[14] P. Bois, D. Huguenota, K. Jézéquel, M. Lollier, J. Y. Cornu, T. Lebeau, Herbicide Mitigation in Microcosms Simulating Stormwater Basins Subject to Polluted Water inputs, Water Res. 2013, 47 (3), 1123-1135.

[15] P. L. Gratão, M. N. V. Prasad, P. F. Cardoso, P. J. Lea, R. A. Azevedo, Phytoremediation: Green Technology for the Clean up of Toxic Metals in the Environment, Braz. J. Plant Physiol. 2005, 17 (1), 53-64.

[16] R. Kamath, J. A. Rentz, J. L. Schnoor, P. J. J. Alvarez, Phytoremediation of hydrocarbon-contaminated soils: Principles and applications, Studies in Surface Science and Catalysis (Eds.: R. Vazquez-Duhalt, R. Quintero-Ramirez), Vol. 151, Elsevier, Amsterdam 2004.

[17] W. Shi, J. Becker, M. Bischoff, R. F. Turco, A. E. Konopka, Association of Microbial Community Composition and Activity With Lead, Chromium, and Hydrocarbon Contamination, Appl. Environ. Microbiol. 2008, 68 (8), 3859-3866.

[18] D. W. Nelson, L. E. Sommers, Total carbon, organic carbon and organic matter, Methods of Soil Analysis, Part 2. Chemical and Microbiological Properties (Eds.: A. L. Page, R. H. Miller, D. R. Keeney), SSSA, Madison, WI 1982, pp. 539-577.

[19] J. M. Bremner, C. S. Mulvaney, Nitrogen-total, Methods of Soil Analysis, Part 2. Chemical and Microbiological Properties (Eds.: A. L. Page, R. H. Miller, D. R. Keeney), SSSA, Madison, WI 1982, pp. 595-624.

[20] S. R. Olsen, L. A. Dean, Phosphorus, Methods of Soil Analysis, Part 2. Chemical and Microbiological Properties (Eds.: A. L. Page, R. H. Miller, D. R. Keeney), SSSA, Madison, WI 1982, pp. 1035-1049.

[21] R. L. Folk, W. C. Ward, Brazos River Bar: A Study in the Significance of Grain Size Parameters, J. Sediment. Petrol. 1957, 27, 3-26.

[22] I. T. A. Moreira, P. F. Freitas, R. S. A. Nascimento, O. M. C. Oliveira, J. A. Triguis, Selection of Species Plant Mangrove for Assessment Phytoremediation of Contaminated Sediments by in Oil and Derivatives, Rio. Oil Gas Expo. Conf. 2010.

[23] I. T. A. Moreira, C. M. S. Martins, M. C. Oliveira, O. M. C. Oliveira, J. A. Triguis, Detailed and confirmatory investigation in an area with contaminated sediment, in order for the application of phytoremediation, XII Workshop and Congress Geochemistry Organic American Latin Association (ALAGO), 2010.

[24] R. S. Romeiro, Métodos em Bacteriologia de Plantas, Viçosa 2001, 1, 279-282.

[25] National Oceanic and Atmospheric Administration (NOAA), Screening Quick Reference Tables, National Oceanic and Atmospheric Administration. NOAA, Seattle, USA 1999.

[26] J. Santos-Echeandia, R. Prego, A. Cobelo-Garcia, Influence of the Heavy Fuel Spill From the Prestige Tanker Wreckage in the Overlying Seawater Column Levels of Copper, Nickel and Vanadium (NE Atlantic Ocean), J. Mar. Syst. 2008, 72, 350-357.

[27] M. Nie, N. Xian, X. Fu, X. Chen, B. Li, The Interactive Effects of Petroleum-Hydrocarbon Spillage and Plant Rhizosphere on Concentrations and Distribution of Metals in Sediments in the Yellow River Delta, China, J. Hazard. Mater. 2010, 174, 156-161.

[28] R. M. Atlas, Petroleum Biodegradation and Oil Spill Bioremediation, Mar. Pollut. Bull. 1995, 31 (4), 178-182.

[29] M. H. Borresen, A. G. Rike, Effects of Nutrient Content, Moisture Content and Salinity on Mineralization of Hexadecane in an Arctic Soil, Cold Reg. Sci. Technol. 2007, 48, 129-138.
[30] S. D. Cunningham, T. A. Anderson, A. P. Schwab, F. C. Hsu, Phytoremediation of Soil Contaminated With Organic Pollutants, Adv. Agron. 1996, 56, 55-71.

[31] N. F. Tam, Y. S. Wong, Effectiveness of Bacterial Inoculum and Mangrove Plants on Remediation of Sediment Contaminated With Polycyclic Aromatic Hydrocarbons, Mar. Pollut. Bull. 2008, 57, 716726.

[32] S. Y. Yuan, J. S. Chang, B. V. Chang, Biodegradation of Phenanthrene in River Sediment, Chemosphere 2001, 43, 273-278.

[33] E. Yergeau, M. Arbour, R. Brousseau, D. Juck, J. R. Lawrence, L. Masson, Microarray and Real-Time PCR Analyses of the Responses of High-Arctic Soil Bacteria to Hydrocarbon Pollution and Bioremediation Treatments, Appl. Environ. Microbiol. 2009, 75 (19), 62586267.

[34] E. Espinosa, M. E. Martinez, E. F. Torres, M. G. Rojas, Improvement of the Hydrocarbon Phytoremediation Rate by Cyperus laxus Lam. Inoculated With a Microbial Consortium in a Model System, Chemosphere 2005, 59 (3), 405-413.

[35] E. J. Joner, S. Corgie, N. Amellal, C. Leyval, Nutritional Constraints to PAH Degradation in a Rhizosphere Model, Soil Biol. Biochem. 2002 , $34,859-864$.

[36] E. Baath, M. Diz-Ravina, A. Frostegard, C. D. Campell, Effect of MetalRich Sludge Amendments on the Soil Microbial Community, Appl. Environ. Microbiol. 1998, 64, 238-245.

[37] M. S. Reddy, S. B. Basha, H. V. Joshi, B. Jha, Evaluation of the Emission Characteristics of Trace Metals From Coal and Fuel Oil Fired Power Plants and Their Fate During Combustion, J. Hazard. Mater. 2005, 123, 242-249.

[38] E. Smits, J. L. Freeman, Environmental Cleanup Using Plants: Biotechnological Advances and Ecological Considerations, Front. Ecol. Environ. 2006, 4, 203-210.

[39] I. T. A. Moreira, O. M. C. Oliveira, J. A. Triguis, A. F. S. Queiroz, C. M. S. Martins, C. S. Silva, R. S. Jesus, Phytoremediation Using Rizophora mangle L. in Mangrove Sediments Contaminated by Persistent Total Petroleum Hydrocarbons (TPH's), Microchem. J. 2011, 4, 376-382.

[40] P. K. Padmavathiamma, Y. L. Loretta, Phytoremediation Technology: Hyper-Accumulation Metals in Plants, Water Air Soil Pollut. 2007, 184, 105-126.

[41] B. E. Abbassi, W. D. Shquirat, Kinetics of Indigenous Isolated Bacteria Used for Ex-Situ Bioremediation of Petroleum Contaminated Soil, Water Air Soil Pollut. 2008, 192, 221-226.

[42] O. Mrklas, L. R. Bentley, S. R. D. Lunn, A. Chu, Principal Component Analyses of Groundwater Chemistry Data During Enhanced Bioremediation, Water Air Soil Pollut. 2006, 169, 395-411.

[43] V. D’Orazio, A. Ghanem, N. Senesi, Phytoremediation of Pyrene Contaminated Soils by Different Plant Species, Water Air Soil Pollut. 2013, 169, 377-382.

[44] X. Long, N. Ni, L. Wang, X. Wang, J. Wang, Z. Zhang, R. Zed, et al., Phytoremediation of Cadmium-Contaminated Soil by Two Jerusalem Artichoke (Helianthus tuberosus L.) Genotypes, Water Air Soil Pollut. 2013, 169, 377-382. 